4. Sandra von Doetinchem. Lifelong Learning: The Essential Element of an Engaged and Active Lifestyle. URL: https://www.asaging.org/blog/lifelong-learning-essential-element-engaged-and-active-lifestyle(дата звернення: 20.03.2020.)

\title{
References
}

1.Active ageing. A policy framework. World Health Organization. URL: http://whqlibdoc.who.int/hq (last access: 09.03.2020).

2.The Government has approved a public policy strategy for healthy and active life expectancy for the period up to 2022 . https://www.msp.gov.ua/news/14645.htm (last access: 15.03.2020).

3.Madrid Plan of Action and its Implementation. URL: https://www.un.org/development/desa/ageing/madrid-plan-of-action-and-itsimplementation.html (last access: 15.03.2020).

4.Sandra von Doetinchem. Lifelong Learning: The Essential Element of an Engaged and Active Lifestyle. URL: https://www.asaging.org/blog/lifelong-learning-essential-element-engaged-and-active-lifestyle (last access: 20.03.2020).

Дата подання публікації 20.03.2020 р.

УДК 336:004.896(07)

Пиріг С. О., к.е.н., доцент

Pyrih S. Candidate of Economic Sciences, Associate Professor https://orcid.org/0000-0002-1205-9814

\section{ВИКОРИСТАННЯ ТАБЛИЧНОГО РЕДАКТОРА МS ЕХСЕL У МЕТОДИЧНІЙ РОБОТІ НАУКОВО-ПЕДАГОГІЧНИХ ПРАЦІВНИКІВ ВИЩОГО НАВЧАЛЬНОГО ЗАКЛАДУ}

\author{
Луцький національний технічний університет
}

\section{У статті розроблено автоматизований шаблон навчального плану для здобувачів вищої освіти за освітнім ступенем «бакалавр» за допомогою табличного редактора MS Excel. \\ Розглянуто один із методів автоматизації методичної роботи на прикладі складання навчального плану засобами офісного пакету, зокрема програми табличного редактора MS Excel, як зручного та зрозумілого у використанні користувачами, які не $є$ фахівцями у галузі інформаційних технологій. \\ Запропоновано та обгрунтовано доцільність використання табличного процесора та його вбудованих функцій зокрема таких функцій, як: СУММ(), СЧЁТЕСЛИ(),СУММЕСЛИ(), ЕСЛИ(), ИЛИ(),СЧЁТЗ(), які допоможуть швидко та просто досягти поставленої мети. \\ Ключові слова: табличний редактор MS Excel, навчальний план, інформаційні технології, інформаційна компетентність, науково-педагогічні працівники. \\ USING THE MS EXCEL TABLE EDITOR IN THE METHODICAL WORK OF SCIENTIFIC AND PEDAGOGICAL WORKERS HIGHER EDUCATIONAL INSTITUTION}

\author{
Lutsk National Technical University
}

The article develops an automated curriculum template for higher education undergraduate students using the MS Excel spreadsheet editor.

One of the methods of automation of methodical work on the example of curriculum development by means of office package, in particular the program of table editor MS Excel, as convenient and clear in use by users who are not experts in the field of information technologies is considered.

The expediency of using a spreadsheet processor and its built-in functions, in particular, such functions as: $\operatorname{SUM}(), \operatorname{COUNTIF}(), \operatorname{SUMIF}(), \operatorname{IF}(), \operatorname{OR}(), \operatorname{COUNTA}()$, which will help to quickly and easily achieve the goal, is proposed and substantiated.

Key words: MS Excel spreadsheet editor, curriculum, information technology, information competence, research and teaching staff.

Постановка проблеми у загальному вигляді i iї зв'язок з важливими науковими та практичними завданнями. Знайти сферу, в якій не використовуються інформаційні технології сьогодні неможливо. Не виключенням $є$ також і заклади вищої освіти, де науково-педагогічні працівники у своїй методичній роботі використовують прикладні програмні засоби загального призначення і звичайно табличний редактор 
Excel, за допомогою якого можна вирішити багато поставлених завдань математичного характеру не вдаючись до програмування.

Розвиток інформаційного суспільства вимагає від сучасних фахівців інформаційно-технологічної компетентності у своїй діяльності. Ступінь володіння засобами інформаційних технологій і навичками управління інформацією показує рівень інформаційної освіти, як науково-педагогічних працівників, так і здобувачів вищої освіти.

Сьогодні ми можемо спостерігати за динамічним розвитком технологій, який змінює наше життя, і нам необхідно бути поряд з цими змінами. Тому, виникає необхідність у підвищенні інформаційно-технологічної компетентності науковопедагогічних працівників для економії часу, який є сьогодні найдорожчим ресурсом та уникнення помилок при виконанні завдань математичного характеру.

Аналіз останніх досліджень, у яких започатковано вирішення проблеми. Використання інформаційних технологій і зокрема табличного процесора Microsoft Excel у професійній діяльності присвячено цілий ряд наукових досліджень, а саме праці таких науковців, як: В. Захожай, О. Мінько, М. Макарової, В. Нелюбова, В. Плескач, Ю. Рамського, та ін.

Цілі статті. Зважаючи на вище сказане, метою даної статті $є$ розроблення автоматизованого шаблону навчального плану для здобувачів вищої освіти за освітнім ступенем «бакалавр» за допомогою табличного редактора MS Excel для підвищення інформаційної компетентності у методичній роботі науково-педагогічних працівників.

Виклад основного матеріалу дослідження 3 повним обгрунтуванням отриманих наукових результатів. Технологія як процес присутня у будь-якій проблемній сфері. Основна мета інформаційної технології (з грецького techne означає уміння) - у результаті засобів та методів одержати потрібну інформацію, яка має грунтуватися на зручності та мінімум витрати часу.

У закладах вищої освіти освітній процес базується на навчальних планах, який $є$ основним та нормативним документом вищого навчального закладу. Розробка навчального плану здійснюється на основі освітніх програм відповідної спеціальності, що містить термін навчання за освітнім ступенем (бакалавр - 3 роки 10 місяців, магістр - 1 рік 4 місяці), загальний бюджет навчального часу (240 - бакалавр, 90 - магістр), перелік обов'язкових та вибіркових дисциплін, їх обсяг у кредитах ЄКТС, послідовність вивчення у відповідних семестрах та форми контролю (залік, екзамен) і т. iн.

Розробка навчального плану є дуже відповідальною та кропіткою роботою науково-педагогічного працівника. Якщо на перший погляд може здатися, що нічого складного у розробці навчального плану немає, то в процесі його розробки з'являється дуже багато запитань щодо правильного його складання.

Перше, що необхідно зробити - автоматизувати шаблон, який наданий університетом для внесення необхідної інформації. Для цього необхідно врахувати усі умови поставлені перед кафедрою вищим навчальним закладом.

Для прикладу розробимо навчальний план для здобувачів вищої освіти за освітнім ступенем «бакалавр» 3 наступними умовами:

- нормативний термін підготовки здобувачів вищої освіти за освітнім ступенем бакалавр становить - 240 кредитів СКТС, де 1 кредит = 30 год;

- обсяг навчального часу на навчальний рік становить 60 кредитів ЄКТС, відповідно семестру - 30 кредитів СКТС;

- обсяг обов'язкової складової не повинна перевищувати 75 \% обсягу (в кредитах (КТС) всього навчального плану i включає навчальні дисципліни, кваліфікаційні роботи, практики та інші види навчального навантаження студента, тобто 180 кредитів СКТС;

- обсяг вибіркової складової має складати не менше 25 \% від загального обсягу програми підготовки, тобто 60 кредитів СКТС; 
- кількість загальних дисциплін вільного вибору - 4, кредитів ЄКТС для кожної дисципліни - 5, форма контролю - залік. Для деяких дисциплін необхідно ставити 1 кредит, 3 кредити, а для деяких таких правил немає (можна від 3 до 10);

- кількість дисциплін у семестрі - 6 (лише у 4, 6 та 8 семестрах враховувати 7ю позицією (у 4 та 6 семестрі) та 5-ю позицією (у 8 семестрі) практику;

- форма контролю - екзамен $\leq 3$ в семестр;

- і так далі.

Кожну з даних умов необхідно врахувати при розробці навчального плану. А в процесі розробки в будь-який час можуть з'являтись ще нові умови (зміни), які за допомогою калькулятора дуже важко вирішити. Тому, автоматизовувати шаблон навчального плану будемо за допомогою програми Excel та іiї вбудованих функцій, які зможуть допомогти у вирішенні даного завдання.

Як зазначалось вище, науково-педагогічні працівники не $\epsilon$ фахівцями інформаційних технологій, але професійна діяльність сьогодні вимагає від них навиків використання програми текстового редактора Word, програми підготовки та перегляду презентацій PowerPoint і звичайно табличного редактора Excel. Тому, використання кількох вбудованих функцій Excel можна автоматизувати підрахунок не тільки кількість аудиторних занять, але й підрахунок екзаменів, заліків, кредитів, дисциплін і таке інше.

На рис. 2 представлений готовий навчальний план зі всіма врахованими умовами. Тому проведемо поетапно автоматизацію даного шаблону.

Першим етапом розробки буде наповнення нашого шаблону необхідними дисциплінами обов'язкову та вибіркову складову враховуючи при цьому 6 дисциплін у семестр. Вказуємо семестр в якому буде викладатися дисципліна, форму контролю (екзамен, залік) та кількість кредитів (діапазон С11:K76). Після чого створюємо формулу для підрахунку та перевірки правильності вказаної кількості дисциплін за семестром у діапазоні AD28:AK29:

\section{$=$ СУММ(СЧЁТЕСЛИ(\$D\$11:\$D\$33;AD28); \\ СЧЁТЕСЛИ(\$D\$36:\$D\$46;AD28); \\ СЧЁТЕСЛИ(\$D\$54:\$D\$57;AD28); \\ СЧЁТЕСЛИ(\$D\$60:\$D\$67;AD28); \\ СЧЁТЕСЛИ(\$D\$72:\$D\$74;AD28))}

В даній формулі функція СУММ() сумує кількість дисциплін у першому семестрі за допомогою вкладеної функції СЧЁТЕСЛИ(), яка перевіряє діапазони \$D\$11:\$D\$33; \$D\$36:\$D\$46; \$D\$54:\$D\$57; \$D\$60:\$D\$67; \$D\$72:\$D\$74 (рис. 2) на наявність у них 1 (одиниці, 1-го семестру - комірка AD28; ... 6-го семестру - AI28...). Якщо у наведених діапазонах буде записано 1 (один), то підраховує наявну кількість дисциплін у першому семестрі (рис. 2). Наявність знаку \$ (долар) робить комірку абсолютною, що означає - незмінність комірки при ії копіювання. Так, як нам необхідно дану формулу скопіювати в інші комірки (AD29:AK29), а перевірка здійснюється у тому ж діапазоні то їх присутність є обов'язковою.

Діапазони комірок, посилання яких вказує на номер семестру (AD28:AK28), мають бути відносними, так, як семестри змінюються від 1-го до 8-го (рис. 1).

\begin{tabular}{|c|c|c|c|c|c|c|c|c|}
\hline & $A D$ & $A E$ & AF & AG & $\mathrm{AH}$ & Al & AJ & $A K$ \\
\hline 28 & 1 & 2 & 3 & 4 & 5 & 6 & 7 & 8 \\
\hline 29 & 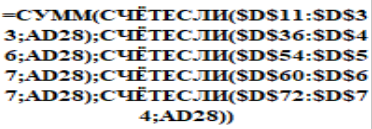 & 6 & 6 & 7 & 6 & 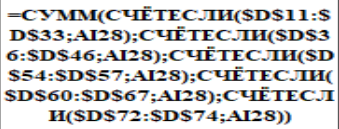 & 6 & 5 \\
\hline 30 & 6 & 6 & 6 & 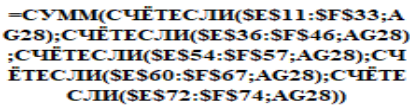 & 6 & 7 & 6 & 5 \\
\hline
\end{tabular}


Рис. 1. Перевірка кількості дисциплін у семестрі (у семестрах 1-5 має бути 6 дисциплін; у 4 та 6 - 7 (6+практика); 8 семестр - 5 (4 + практика)

\begin{tabular}{|c|c|c|c|c|c|c|c|c|c|c|c|c|c|c|}
\hline & B & $\mathrm{C}$ & D & \begin{tabular}{|l|l|}
$\mathrm{E}$ \\
\end{tabular} & $\mathrm{F}$ & \begin{tabular}{|l|l}
$\mathrm{H}$ \\
\end{tabular} & $\mathrm{I}$ & $\mathrm{J}$ & $\mathrm{K}$ & $\mathrm{L}$ & $\mathrm{M}$ & $\mathrm{N}$ & $\mathrm{O}$ & $\mathrm{P}$ \\
\hline 2 & & & & & & Іан н & навч & чально & 10го II & Іроцесу & & & & \\
\hline 3 & & & & & & & & & n & & & Кільк & кість го & годин \\
\hline 4 & & & & & Семе & естро & вии т & та та & E & & & Aулитопn & nні эан & 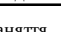 \\
\hline 5 & Шифр & & & & & & & & $\mathscr{m}$ & & & Аудитор & PHI 3at & НАЯІМ \\
\hline 6 & навчаль- & & है & & & $\bar{z}$ & $\Xi$ & $\mid \frac{1}{\mathrm{~m}}$ & 鹿 & & 當 & & з ни & \\
\hline 7 & $\begin{array}{c}\text { них } \\
\text { дисциплін } \\
\mathbf{i} \text { практик }\end{array}$ & НАЗВА ДИСЦИПЛІНИ & & 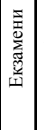 & 咅 & 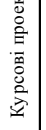 & 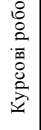 & 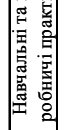 & 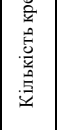 & 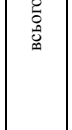 & 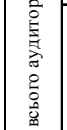 & 壱 & 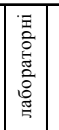 & 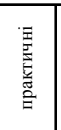 \\
\hline 8 & 1 & 2 & 3 & 4 & 5 & 7 & 8 & 9 & 10 & 11 & 12 & 13 & 14 & 15 \\
\hline 99 & & & & & & 1. $\mathrm{O}$ & бов' & 'язкова & а склад & дова & & & & \\
\hline 10 & & & & & $.1 . д_{1}$ & исциг & пллін & ни загал & льної п & підготов & Вки & & & \\
\hline 11 & ДЗП.ОС.01 & Дисципліна 1 & 2 & & 2 & & & & 5 & 150 & 60 & 30 & & 30 \\
\hline 12 & ДЗП.ОС.02 & Дисципліна 2 & 1 & 1 & & & & & 5 & 150 & 60 & 30 & & 30 \\
\hline 13 & ДЗП.ОС.03 & Дисципліна 3 & \begin{tabular}{|l|l|}
3 \\
\end{tabular} & & 3 & & & & 6 & 180 & 60 & 30 & & 30 \\
\hline 14 & ДЗП.ОС.04 & Дисципліна 4 & 1 & & 1 & & & & 5 & 150 & 60 & 30 & & 30 \\
\hline 15 & & & 1 & & 1 & & & & 3 & 90 & 30 & & & 30 \\
\hline 16 & & Јирем и иоре & \begin{tabular}{|l|}
2 \\
\end{tabular} & & 2 & & & & 3 & 90 & 30 & & & 30 \\
\hline 17 & 2311.0С. 05 & Іноземна мова за професійним спрямуванням & \begin{tabular}{|l|}
3 \\
\end{tabular} & & 3 & & & & 3 & 90 & 30 & & & 30 \\
\hline 18 & & & \begin{tabular}{|l|}
4 \\
\end{tabular} & & 4 & & & & 2 & 60 & 30 & & & 30 \\
\hline 19 & & & 1 & & 1 & & & & 1 & 30 & 30 & & & 30 \\
\hline 20 & ДЗП.ОС.06 & Фізичне виховання & \begin{tabular}{|l|}
2 \\
\end{tabular} & & 2 & & & & 1 & 30 & 30 & & & 30 \\
\hline 21 & & & \begin{tabular}{|l|}
3 \\
\end{tabular} & & 3 & & & & 1 & 30 & 30 & & & 30 \\
\hline 22 & ДЗП.ОС.07 & Дисципліна 7 & 5 & 5 & & & & & 5 & 150 & 60 & 30 & & 30 \\
\hline 23 & ДЗП.ОС.08 & Дисципліна 8 & 1 & 1 & & & & & 8 & 240 & 90 & 30 & 30 & 30 \\
\hline 24 & \begin{tabular}{|l|} 
ДЗП.ОС.09 \\
\end{tabular} & Дисципліна 9 & \begin{tabular}{|l|l|}
4 \\
\end{tabular} & 4 & & & & & 5 & 150 & 60 & 30 & & 30 \\
\hline 25 & ДЗП.ОС.10 & Дисципліна 10 & 4 & & 4 & & & & 5 & 150 & 60 & 30 & & 30 \\
\hline 26 & ДЗП.ОС.11 & Дисципліна 11 & \begin{tabular}{|c|}
6 \\
\end{tabular} & & 6 & & & & 5 & 150 & 60 & 30 & & 30 \\
\hline 27 & ДЗП.ОС.12 & Дисципліна 12 & \begin{tabular}{|c|}
6 \\
\end{tabular} & 6 & & & & & 5 & 150 & 60 & 30 & 30 & \\
\hline 28 & ДЗП.ОС.13 & Дисципліна 13 & 4 & 4 & & & & & 5 & 150 & 60 & 30 & & 30 \\
\hline 29 & ДЗП.ОС.14 & Дисципліна 14 & 8 & 8 & & 8 & & & 7 & 210 & 60 & 30 & & 30 \\
\hline 30 & ДЗП.ОС.15 & Дисципліна 15 & 6 & 6 & & 6 & & & 4 & 120 & 60 & 30 & & 30 \\
\hline 31 & ДЗП.ОС.16 & Дисципліна 16 & \begin{tabular}{|c|}
6 \\
\end{tabular} & 6 & & & & & 4 & 120 & 60 & 30 & & 30 \\
\hline 32 & ДЗП.ОС.17 & Дисципліна 17 & 1 & 1 & & & & & 8 & 240 & 90 & 30 & 30 & 30 \\
\hline 33 & ДЗП.ОС.18 & Дисципліна 18 & 7 & & 7 & & & & 5 & 150 & 60 & 30 & & 30 \\
\hline 34 & & АЗОМ дисципліни загальної підготовки & & $10 \mid$ & 13 & 2 & & & 101 & 3030 & 1230 & 480 & 90 & 660 \\
\hline 35 & & & & & 2. Дис & сципл & лліни & и профес & есійної & ї підгото & овки & & & \\
\hline 36 & \begin{tabular}{|l|} 
ДПП.ОС.01 \\
\end{tabular} & Дисципліна 1 & \begin{tabular}{|l|l}
2 &
\end{tabular} & 2 & & & & & 7 & 210 & 90 & 30 & 30 & 30 \\
\hline 37. & ДПП.ОС.02 & Дисципліна 2 & 2 & 2 & & & & & 7 & 210 & 90 & 30 & 30 & 30 \\
\hline 38 & ДПП.ОС.03 & Дисципліна 3 & 2 & 2 & & & & & 7 & 210 & 90 & 30 & 30 & 30 \\
\hline 39. & ДПП.ОС.04 & Дисципліна 4 & 3 & 3 & & 3 & & & 8 & 240 & 90 & 30 & 30 & 30 \\
\hline 40 & ДПП.ОС.05 & Дисципліна 5 & \begin{tabular}{|c|c|}
8 & \\
\end{tabular} & 8 & & & & & 5 & 150 & 45 & 30 & & 15 \\
\hline 41. & ДПП.ОС.06 & Дисципліна 6 & 7 & 7 & & 7 & & & 5 & 150 & 60 & 30 & & 30 \\
\hline 42. & ДПП.ОС.07 & Дисципліна 7 & 4 & 4 & & 4 & & & 5 & 150 & 60 & 30 & & 30 \\
\hline 43. & ДПП.ОС.08 & Дисципліна 8 & 5 & 5 & & 5 & & & 5 & 150 & 60 & 30 & & 30 \\
\hline 44. & ДПП.ОС.09 & Дисципліна 9 & 7 & 7 & & & & & 6 & 180 & 60 & 30 & & 30 \\
\hline 45 . & ДПП.ОС.10 & Дисципліна 10 & 7 & & 7 & & & & 5 & 150 & 60 & 30 & 30 & \\
\hline 46 & дПП.ОС.14 & Дисципліна 11 & 8 & & 8 & & & & 3 & 90 & 45 & 30 & & 15 \\
\hline 47 & & ЗОМдисципліни професійної підготовки & & 9 & 2 & 4 & & & 63 & 1890 & 750 & 330 & 150 & 270 \\
\hline 48 & & РАЗОМЗА ЦИКЛОМ 1. & & 19 & 15 & 6 & & & 164 & 4920 & 1980 & 810 & 240 & \begin{tabular}{|l|l|}
930 \\
\end{tabular} \\
\hline 49 & & & & & Виб̆́ & ірков & васк & кладова & а (вибї & ір студен & ннта) & & & \\
\hline 50 & & & & & .3 ara & альні & і дисг & сциплін & ни віль & Іьного ви & ибору & & & \\
\hline 54 & ЗД.ВС.01 & Дисципліна 1 & \begin{tabular}{|c|c|}
3 & \\
\end{tabular} & & 3 & & & & 5 & 150 & 60 & 30 & & 30 \\
\hline 55 & 3Д.ВС.02 & Дисципліна 2 & 4 & & 4 & & & & 5 & 150 & 60 & 30 & & 30 \\
\hline 56 & ЗД.ВС.03 & Дисципліна 3 & 5 & & 5 & & & & 5 & 150 & 60 & 30 & & 30 \\
\hline 57 & \begin{tabular}{|l|} 
3Д.ВС.04 \\
\end{tabular} & Дисципліна 4 & 6 & & 6 & & & & 5 & 150 & 60 & 30 & & 30 \\
\hline 58 & & PA3OM & & 0 & 4 & 0 & & & 20 & 600 & 240 & 120 & 0 & \begin{tabular}{|l|}
120 \\
\end{tabular} \\
\hline 59 & & & & $2 . \Pi_{t}$ & דроф & есій̈ & нi $\partial u$ & исциилі & інин віл & Льного в & вибору & & & \\
\hline 60 & \begin{tabular}{|l|} 
ПД.ВС.01 \\
\end{tabular} & Дисципліна 1 & \begin{tabular}{|l|}
5 \\
\end{tabular} & & 5 & & & & 5 & 150 & 60 & 30 & & 30 \\
\hline 61 & ПД.ВС.02 & Дисципліна 2 & 5 & & 5 & & & & 5 & 150 & 60 & 30 & & 30 \\
\hline 62 & \begin{tabular}{|l|} 
ПД.ВС. 03 \\
\end{tabular} & Дисципліна 3 & \begin{tabular}{|l|}
7 \\
\end{tabular} & & 7 & & & & 4 & 120 & 60 & 30 & & 30 \\
\hline 63 & ПД.ВС. 04 & Дисципліна 4 & \begin{tabular}{|l|}
8 \\
\end{tabular} & 8 & & & & & 5 & 150 & 45 & 30 & 15 & \\
\hline 64 & ПД.ВС. 05 & Дисципліна 5 & 6 & & 6 & & & & 4 & 120 & 60 & 30 & & 30 \\
\hline 65 & ПД.ВС.06 & Дисципліна 6 & 3 & 3 & & & & & 7 & 210 & 60 & 30 & & 30 \\
\hline 66 & \begin{tabular}{|l|} 
ПД.ВС. 07 \\
\end{tabular} & Дисципліна 7 & 5 & 5 & & & & & 5 & 150 & 60 & 30 & & 30 \\
\hline 67 & \begin{tabular}{|l|} 
ПД.ВС. 08 \\
\end{tabular} & Дисципліна 8 & 7 & 7 & & & & & 5 & 150 & 60 & 30 & & 30 \\
\hline 68 & PA30 & ОМ професійні дисципліни вільного вибору & & 4 & 4 & & & & 40 & 1200 & 465 & 240 & 15 & 210 \\
\hline 69 & & РАЗОМ дисципліни вільного вибору & & 4 & 8 & $\mathbf{0}$ & & & 60 & 1800 & 705 & 360 & 15 & 330 \\
\hline 70 & & РАЗОМЗА ЦИКЛАММ 1-2 & & 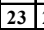 & 23 & 6 & & & 224 & \begin{tabular}{l|l|l}
6720 & \\
\end{tabular} & 2685 & 1170 & 255 & 1260 \\
\hline 71 & & & & & & IIPAK & КТИ' & IUHA III & ІІдГо & TOBKA & & & & \\
\hline 72 & 3.1 & Практика I & 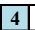 & & 4 & & & & 3 & 90 & & & & \\
\hline 73 & 3.2 & Практика II & 6 & & 6 & & & & 3 & 90 & & & & \\
\hline 74 & 3.3 & Переддипломна практика & 8 & & 8 & & & & 5 & 150 & & & & \\
\hline 75 & & & & & & ПІІД & $C$ & MI & A ATE & СТАЦИ & & & & \\
\hline 76 & 4.1 & Підготовка та захист кваліфікаційної роботи & \begin{tabular}{|l|l}
8 \\
\end{tabular} & & & & & & 5 & 150 & & & & \\
\hline 77 & & Всього за циклом 3 і 4: & & & 3 & & & & 16 & 480 & & & & \\
\hline 78 & & & & & & & & & & & & & & \\
\hline 79 & Курсові про & оєкти (роботи): & & & & & & & & & & & & \\
\hline 80 & Кількість е & екзаменів: & & & & & & & & & & & & \\
\hline 81 & Кількість 3 & заліків: & & & & & & & & & & & & \\
\hline 82 & Практики/c & стажування/тренінги & & & & & & & & & & & & \\
\hline 84 & Вироб̆нича & практика: & & & & & & & & & & & & \\
\hline 85 & Переддипл & омна практика: & & & & & & & & & & & & \\
\hline 86 & Підготовка & та захист кваліфікаційної роботи & & & & & & & & & & & & \\
\hline 87. & Атестаційн & чий екзамен & & & & & & & & & & & & \\
\hline 88 & Разом за на & вччальним планом: & & 23 & 26 & & & & 240 & 7200 & 2685 & 1170 & 255 & 1260 \\
\hline
\end{tabular}


Рис. 2. Навчальний план з усіма врахованими умовами (формулу 2):

У діапазоні (AD30:AK30, рис. 1) можна записати трішки іншу формулу

$$
\begin{gathered}
\text { =СУММ(СЧЁТЕСЛИ(\$Е\$11:\$F\$33;AD28); } \\
\text { СЧЁТЕСЛИ(\$Е\$36:\$F\$46;AD28); } \\
\text { СЧЁТЕСЛИ(\$E\$54:\$F\$57;AD28); } \\
\text { СЧЁТЕСЛИ(\$E\$60:\$F\$67;AD28); } \\
\text { СЧЁТЕСЛИ(\$E\$72:\$F\$74;AD28)) }
\end{gathered}
$$

Формула 2 здійснить таку ж операцію, як попередня формула 1, але вона буде перевіряти і сумувати кількість дисциплін у діапазонах, де записані екзамени та заліки відносно семестру, що забезпечить здійснення помилки на етапі підрахунку кількості екзаменів та заліків (помилка полягає у неправильному записі екзамену чи заліку відносно семестру - замість $4-3$ або 5, це може відбутися при зміні семестру). Їх розмістимо поряд, щоб відразу перевірити правильність введення екзаменів та заліків відносно семестрів.

Наступну формулу запишемо у комірку AD35 і скопіюємо в діапазон комірок AE35:AK35:

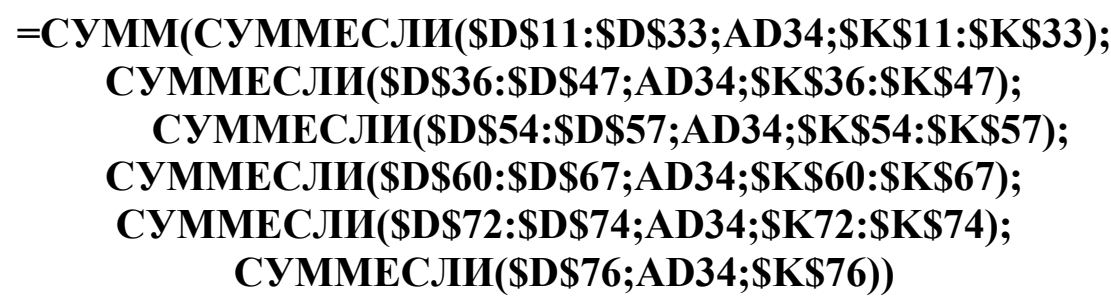

За допомогою формули 3 ми здійснимо підрахунок кредитів, які записані у стовпці K (кількість кредитів ECTS) відносно стовпця D (семестр, рис. 2). Формула та іiі результат наведені на рис. 3 .

В даній формулі функція СУММ() буде підсумовувати кількість кредитів, які

\begin{tabular}{|c|c|c|c|c|c|c|c|c|}
\hline 4 & $A D$ & $\mathrm{AE}$ & $\mathrm{AF}$ & AG & $\mathrm{AH}$ & Al & AJ & AK \\
\hline 34 & 1 & 2 & 3 & 4 & 5 & 6 & 7 & 8 \\
\hline 35 & 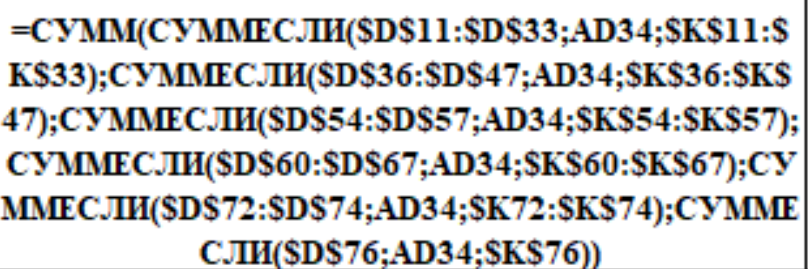 & 30 & 30 & 30 & 30 & 30 & 30 & 30 \\
\hline
\end{tabular}
буде відбирати та сумувати функція СУММЕСЛИ(), яка переглядає діапазон комірок стовпця D (\$D\$11:\$D\$33; \$D\$36:\$D\$46; \$D\$54:\$D\$57; \$D\$60:\$D\$67; \$D\$72:\$D\$74, рис. 2) і якщо у ньому знаходить 1 (1-й семестр, комірка AD34), то сумує кількість кредитів у стовпчику К.

Рис. 3. Перевірка кількості кредитів у семестрі (30 кредитів)

Наприклад: у комірці D12=1 (AD34) $\rightarrow \mathrm{K} 12=5$; D14=1 $\rightarrow \mathrm{K} 14=5 ; \mathrm{D} 15=1 \rightarrow$ $\mathrm{K} 15=3 ; \mathrm{D} 19=1 \rightarrow \mathrm{K} 19=1 ; \mathrm{D} 23=1 \rightarrow \mathrm{K} 23=8 ; \mathrm{D} 32=1 \rightarrow \mathrm{K} 32=8$ (рис. 4). Результатом формули буде $30(5+5+3+1+8+8)$. 


\begin{tabular}{|c|c|c|c|c|c|c|c|c|c|c|c|c|c|c|c|c|c|c|c|c|c|c|c|c|}
\hline A & B & C & $\mathrm{D}$ & E & $\mathrm{F}$ & $\mathrm{H}$ & 1 & $J$ & K & $\mathrm{L}$ & M & $\mathrm{N}$ & 0 & $\mathrm{P}$ & Q & $\mathrm{R}$ & S & $T$ & U & $\mathrm{v}$ V & $w>x$ & $x$ & $y \mid z$ & $Z A A$ \\
\hline 11 & ДЗП.ОС.01 & Дисципліна 1 & \begin{tabular}{|l|l|l}
2 \\
\end{tabular} & & 2 & & & & 5 & 150 & 60 & 30 & & 30 & & & 90 & & 4 & & & & & \\
\hline 12 & ДЗП.ОС.02 & Дисципліна 2 & 1 & 1 & & & & & 5 & 150 & 60 & 30 & & 30 & & & 90 & 4 & & & & & & \\
\hline 13 & дзП.ОС.03 & Дисципліна 3 & 3 & & 3 & & & & 6 & 180 & 60 & 30 & & 30 & & & 120 & & & 4 & & & & \\
\hline 14 & ДЗП.ОС.04 & Дисципліна 4 & 1 & & 1 & & & & 5 & 150 & 60 & 30 & & 30 & & & 90 & 4 & & & & & & \\
\hline 15 & \multirow{4}{*}{ ДЗП.ОС.05 } & \multirow{4}{*}{ Іноземна мова за професійним спрямуванням } & 1 & & 1 & & & & 3 & 90 & 30 & & & 30 & & & 60 & 2 & & & & & & \\
\hline 16 & & & 2 & & 2 & & & & 3 & 90 & 30 & & & 30 & & & 60 & & 2 & & & & & \\
\hline 17 & & & \begin{tabular}{|c|}
3 \\
\end{tabular} & & 3 & & & & 3 & 90 & 30 & & & 30 & & & 60 & & & 2 & & & & \\
\hline 18 & & & 4 & & 4 & & & & 2 & 60 & 30 & & & 30 & & & 30 & & & & 2 & & & \\
\hline 19 & \multirow{3}{*}{ ДЗП.ОС. 06} & \multirow{3}{*}{ Фізичне виховання } & 1 & & 1 & & & & 1 & 30 & 30 & & & 30 & & & 0 & \begin{tabular}{|l|l|l|}
2 & \\
\end{tabular} & & & & & & \\
\hline 20 & & & \begin{tabular}{|l|}
2 \\
\end{tabular} & & 2 & & & & 1 & 30 & 30 & & & 30 & & & 0 & & 2 & & & & & \\
\hline 21 & & & 3 & & 3 & & & & 1 & 30 & 30 & & & 30 & & & 0 & & & 2 & & & & \\
\hline 22 & дЗП.ОС.07 & Дисципліна 7 & 5 & 5 & & & & & 5 & 150 & 60 & 30 & & 30 & & & 90 & & & & & 4 & & \\
\hline 23 & ДЗП.ос.08 & Дисципліна 8 & 1 & 1 & & & & & 8 & 240 & 90 & 30 & 30 & 30 & & & 150 & 6 & & & & & & \\
\hline 24 & ДЗП.ОС.09 & Дисципліна 9 & 4 & 4 & & & & & 5 & 150 & 60 & 30 & & 30 & & & 90 & & & & 4 & & & \\
\hline 25 & ДЗП.ОС.10 & Дисциплтіна 10 & 4 & & 4 & & & & 5 & 150 & 60 & 30 & & 30 & & & 90 & & & & 4 & & & \\
\hline 26 & ДЗП.ОС.11 & Дисципліна 11 & 6 & & 6 & & & & 5 & 150 & 60 & 30 & & 30 & & & 90 & & & & & & 4 & \\
\hline 27 & ДЗП.ОС.12 & Дисциплтіна 12 & 6 & 6 & & & & & 5 & 150 & 60 & 30 & 30 & & & & 90 & & & & & & 4 & \\
\hline 28 & ДЗП.ОС.13 & Дисципліна 13 & 4 & 4 & & & & & 5 & 150 & 60 & 30 & & 30 & & & 90 & & & & 4 & & & \\
\hline 29 & ДЗП.ОС.14 & Дисципліна 14 & 8 & 8 & & 8 & & & 7 & 210 & 60 & 30 & & 30 & & & 150 & & & & & & & 9 \\
\hline 30 & ДЗП.ОС.15 & Дисципліна 15 & 6 & 6 & & 6 & & & 4 & 120 & 60 & 30 & & 30 & & & 60 & & & & & & 4 & \\
\hline 31 & ДЗП.ОС.16 & Дисципліна 16 & 6 & 6 & & & & & 4 & 120 & 60 & 30 & & 30 & & & 60 & & & & & & 4 & \\
\hline 32 & ДЗП.ОС.17 & Дисциплтіна 17 & 1 & 1 & & & & & 8 & 240 & 90 & 30 & 30 & 30 & & & 150 & 6 & & & & & & \\
\hline 33 & дЗП.ОС.18 & Дисципліна 18 & 7 & & 7 & & & & 5 & 150 & 60 & 30 & & 30 & & & 90 & & & & & & & 4 \\
\hline
\end{tabular}

Рис. 4. Підрахунок кількості кредитів у першому семестрі за допомогою формули 3

На основі результатів, які будуть формуватись під час заповнення навчального плану (рис. 1 та 3) можна побудувати динаміку кількості кредитів та дисциплін за семестрами для наочнішого спостереження відхилень від поставлених умов (у 5 семестрі необхідно добавити 10 кредитів, а у 6 зменшити на 10 кредитів, рисунок 1) та швидкого їх корегування.

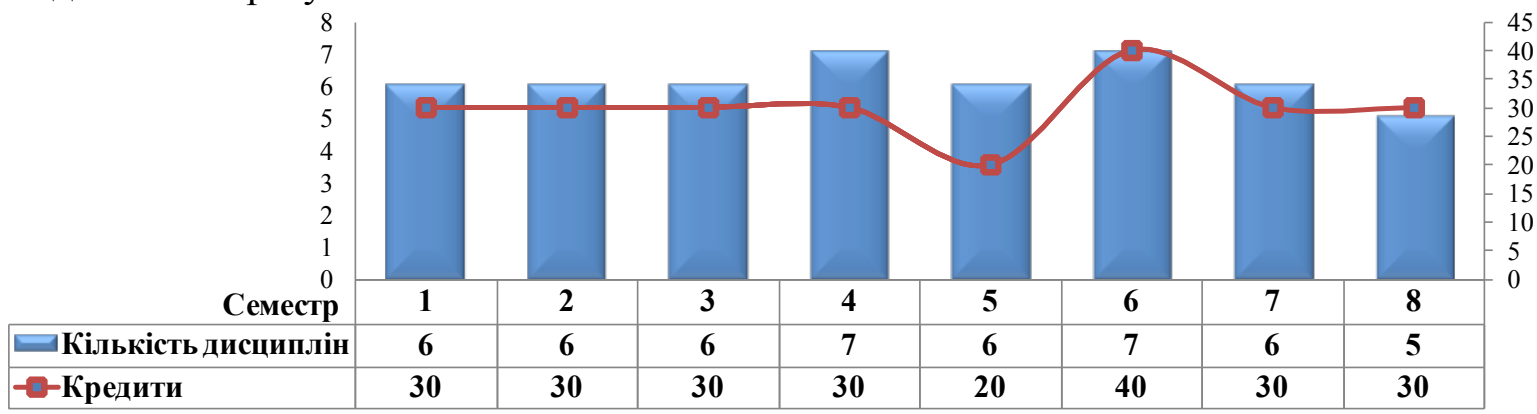

Рис. 5. Графічний вигляд результату підрахунку кількості кредитів та дисциплін

Щоб перевірити умови щодо обсягу обов'язкової та вибіркової складової кредитів дисциплін необхідно записати формули, що наведені на рис. 6. На основі записаних формул є можливість швидко виправити відхилення від заданих умов.

\begin{tabular}{|c|c|c|c|c|c|}
\hline 4 & $A D$ & $\mathrm{AE}$ & $\mathrm{AF}$ & AG & AH \\
\hline 38 & \multicolumn{2}{|c|}{ ОБОВЯ'ЗКОВА СКЛАДОВА } & \multicolumn{2}{|c|}{ ВИБІРКОВА СКЛАДОВА } & Разом \\
\hline 39 & $=(\mathrm{K} 34+\mathrm{K} 47+\mathrm{K} 77) / \mathrm{SK} \$ 88$ & $75 \%$ & $=\mathrm{K} 69 / \mathrm{K} 88$ & $25 \%$ & $100 \%$ \\
\hline 40 & $=\mathrm{K} 34+\mathrm{K} 47+\mathrm{K} 77$ & 180 & $=\mathrm{K} 69$ & 60 & 240 \\
\hline
\end{tabular}

Рис. 6. Перевірка обсягу обов'язкової та вибіркової складової у кількості кредитів та \%

Формули, що наведені на рис. 7 допоможуть порахувати кількість курсових робіт (у першому семестрі комірка Т79), кількість екзаменів (у першому семестрі комірка Т80) та кількість заліків (у першому семестрі комірка T81). I якщо виявиться, 
що $є$ відхилення від заданих умов (екзамен $\leq 3), \epsilon$ можливість швидко їх уникнути зробивши необхідні виправлення.

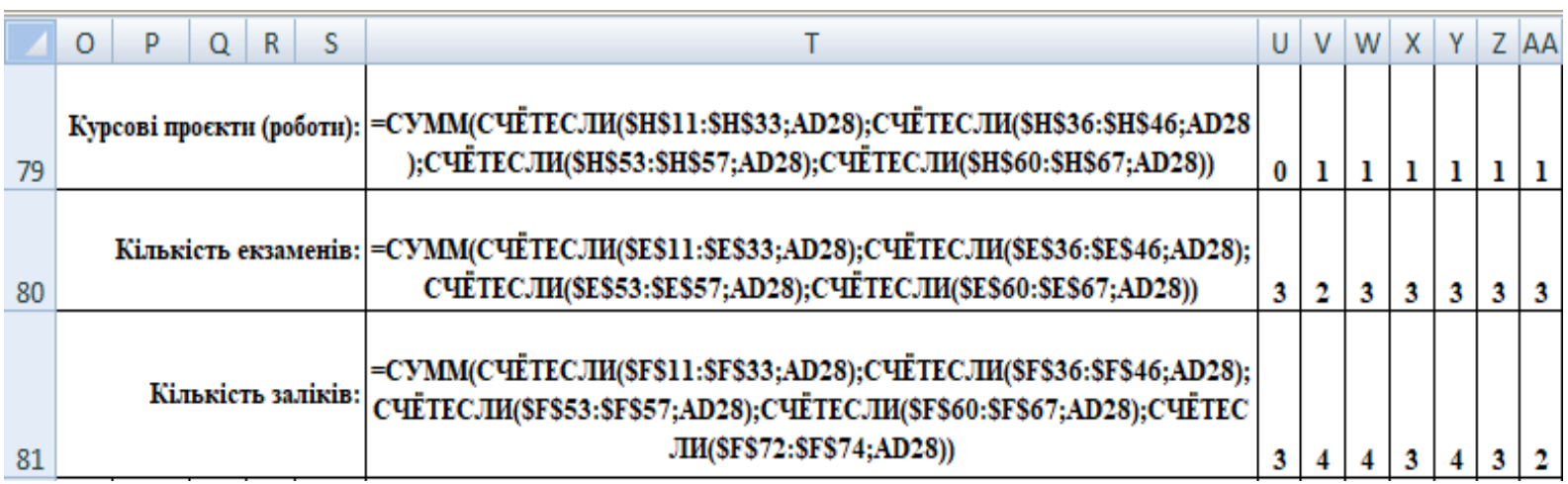

Рис. 7. Перевірка кількості курсових, екзаменів та заліків у семестрі

Для підрахунку кількості кредитів та аудиторних i самостійних год використовуємо функцію СУММ(), яка не вимагає пояснень щодо іiі роботи. А підрахунок екзаменів, заліків та курсових будемо здійснювати за допомогою функцію СЧЁТЗ(), яка на відміну від функції СЧЁТ (яка рахує лише числа у діапазоні комірок) рахує усі непусті комірки (і числа і символи Н43). У стовпці $\mathrm{H}$, де зазначені курсові роботи, є можливість писати символ К (курсова), або ж цифру, яка буде вказувати на курсову роботу у відповідному семестрі (рис. 8).

\begin{tabular}{|c|c|c|c|c|c|c|c|}
\hline 14 & c & D & E & $\mathrm{F}$ & H & \begin{tabular}{l|l} 
& $J$
\end{tabular} & $\mathrm{k}$ \\
\hline 36 & Дисципліна 1 & 2 & 2 & & & & 7 \\
\hline 37 & Дисципліна 2 & 2 & 2 & & & & 7 \\
\hline 38 & Дисципліна 3 & 2 & 2 & & & & 7 \\
\hline 39 & Дисципліна 4 & 3 & 3 & & 3 & & 8 \\
\hline 40 & Дисциплтіна 5 & 8 & 8 & & & & 5 \\
\hline 41 & Дисципліна 6 & 7 & 7 & & 7 & & 5 \\
\hline 42 & Дисциплтіна 7 & 4 & 4 & & 4 & & 5 \\
\hline 43 & Дисциплтіна 8 & 5 & 5 & & $\mathbf{K}$ & & 5 \\
\hline 44 & Дисциплиіна 9 & 7 & 7 & & & & 6 \\
\hline 45 & Дисциплтіна 10 & 7 & & 7 & & & 5 \\
\hline 46 & Дисципліна 11 & 8 & & 8 & & & 3 \\
\hline 47 & 3ОМ дисцитліни & & $=$ =CUËT3(E36:E46) & $=$ =CUËT3(F36:F46) & $=$ =CUËТ3(H36:H46) & & =CYMM(K36:K46) \\
\hline 48 & Результат & & 9 & 2 & 4 & & 63 \\
\hline
\end{tabular}

Рис. 8. Підрахунок кількості курсових, екзаменів та заліків

\begin{tabular}{|c|c|c|c|c|c|c|c|c|c|c|c|c|c|c|c|}
\hline 4 & L & $M$ & $\mathrm{~N}$ & 0 & $\mathrm{P}$ & $\mathrm{Q}$ & $R$ & $S$ & $\mathrm{~T}$ & U & V & W & $x$ & Y & $\mathrm{ZA}$ \\
\hline 36 & 210 & 90 & 30 & 30 & 30 & & & 120 & & 6 & & & & & \\
\hline 37 & 210 & \multirow{3}{*}{\multicolumn{14}{|c|}{$\begin{array}{c}=\text { ЕС ЛИ(ИЛИ(Е42=4;F42=4);(N42+O42+P42+Q42)/15;" ") } \\
=\text { ЕС.ЛИ((D42=4;N42+042+P42+Q42)/15;" ") } \\
=\text { ЕС.ЛИ(D42=W5;(N42+042+P42+Q42)/15;" ") }\end{array}$}} \\
\hline 38 & 210 & & & & & & & & & & & & & & \\
\hline 39 & 240 & & & & & & & & & & & & & & \\
\hline 40 & 150 & 45 & 30 & & 15 & & & 105 & & & & & & & 7 \\
\hline 41 & 150 & 60 & 30 & & 30 & & & 90 & & & & & & & 4 \\
\hline 42 & 150 & 60 & 30 & & 30 & & & 90 & & & & 4 & & & \\
\hline 43 & 150 & 60 & 30 & & 30 & & & 90 & & & & & 4 & & \\
\hline
\end{tabular}

Рис. 9. Підрахунок кількості курсових, екзаменів та заліків 
На рис. 9 представлені формули, які обчислять кількість годин у тиждень (час відведений на викладання дисципліни на навчальний тиждень) за вказаними аудиторними годинами та дисципліною, де $\mathrm{N}$ - лекції, $\mathrm{O}$ - лабораторні, $\mathrm{P}$ - практичні, $\mathrm{Q}$ - семінарські заняття, 15 - навчальних тижнів у семестр.

Висновки. Таким чином, автоматизація розробленого шаблону навчального плану дозволить науково-педагогічним працівникам зменшити витрати часу на його складання і виправлення у випадку змін щодо поставлених умов.

\section{Список бібліографічного опису:}

1.Мінько О.О. Сучасний аналіз даних в Excel для науковців. Науково-учбовий центр прикладної інформатики НАН України. Третє вид. виправлене. Київ: НУЦ ПІ НАНУ, 2018. 461 с. URL :https://ru.calameo.com/read/ $0031683721 \mathrm{a} 4 \mathrm{~b} 517 \mathrm{a} 668 \mathrm{~b}$ (дата звернення 01.03.2020).

2.Рамський Ю.С. Інформаційне суспільство. Інформатизація освіти. Науковий часопис НПУ імені М.П. Драгоманова. Серія №2. Комп’ютерно-орієнтовані системи навчання : зб. наук. Праць. Редрада. К. : НПУ імені М.П. Драгоманова, 2010. № 7

\section{References:}

1. Minko O.O (2018) Modern data analysis in Excel for scientists. Research and Training Center for Applied Informatics of the National Academy of Sciences of Ukraine. The third kind. corrected. Kyiv: NUTS PI NASU. 461. Retrieved from https:// ru.calameo.com/read/ 0031683721a4b517a668b [in Ukrainian].

2. Ramsky Y.S. (2010) Information society. Informatization of education. Scientific journal of NPU named after MP Драгоманова. Series №2. Computer-based learning systems: Coll. Science. Works. Redrada. K .: NPU named after MP Dragomanova, 7. [in Ukrainian].

Дата подання публікації 15.03.2020 p. 